\title{
FLG wt Allele
}

National Cancer Institute

\section{Source}

National Cancer Institute. FLG wt Allele. NCI Thesaurus. Code C112149.

Human FLG wild-type allele is located in the vicinity of $1 \mathrm{q} 21.3$ and is approximately $23 \mathrm{~kb}$ in length. This allele, which encodes filagg rin protein, plays a role in promoting disulfidebond formation in intermediate filaments. Mutations in this gene are associated with ichthyosis vulgaris and with susceptibility to atopic dermatitis type 2 . 